\title{
How far are we? Information from the three decades of ethnomedicinal studies in Thailand
}

Methee Phumthum 1, 2

\begin{abstract}
Ethnobotany has been an academic discipline for more than a century. In Thailand, it was introduced into academia only 30 years ago, but the study has been carried on extensively. This study aims to analyze the number of ethnomedicinal reports based in Thailand and guide the design of future studies. The details include studied villages and ethnic groups from publications appearing during the course of the last 30 years. Ethnomedicinal reports were collected from online databases - Google Scholar, Scopus, PubMed - and university libraries in Thailand. The other literature sources were Thai journals and the website of the Thai Library Integrated System. The period of publications ranges from 1990 to 2019. During this period, a total of 146 publications (student theses, journal articles, scientific reports, and a book) were published from 32 universities and research institutes in Thailand. The publications revealed records of plants used by 223 villages in 25 ethnic groups overall in Thai regions. Although ethnobotany started in Thailand after 70 years of a continuous track record in other parts of the world, the success in Thailand is reflected in the high number of studies and studied villages. However, more studies need to be done in many other villages and ethnic groups in the country before the subject can be considered well broached.
\end{abstract}

Keywords: Traditional Knowledge; Ethnobotany; Medicinal Plants; Ethnomedicinal Reports; Ethnic Groups

1 Department of Pharmaceutical Botany, Faculty of Pharmacy, Mahidol University, Bangkok, Thailand.

2 Sireeruckhacharti Nature Learning Park, Mahidol University, Nakhon Pathom, Thailand.

* Corresponding author. $₫ \mathrm{E}$-mail address: Methee Phumthum (methee.phu@mahidol.edu)

\section{SIGNIFICANCE STATEMENT}

This study highlights overview the status of ethnomedicinal study, which has been introduced to the Thai educational system for 30 years. Researchers from institutes and universities in all areas of Thailand have been work extensively on the ethnomedicinal study. The researchers have visited hundreds of villages from 25 ethnic groups living in Thailand. 


\section{INTRODUCTION}

Plants have been cultural, symbolic and medicinal importance to humanity since before recorded history. Due to the preservation of knowledge in the written language in modern times, we have the ability to understand the importance of plants to humankind over the course of several millennia. A revolutionary work on useful plants was showed up in the first century AD by the Greek physician, Dioscorides (Touwaide et al. 1997). However, the distinction between traditional and allopathic medicine didn't become apparent until modern times. The word 'ethnobotany' didn't enter the English language for more than 1800 years after the work of Dioscorides was showed up, when it was first defined by John Harsberger in 1896 (Harshberger 1896). In recent memory, ethnobotany gained fame when Richard Evans Schultes, who is considered as the father of modern ethnobotany, popularized the Amazonian region after publishing several influential studies (Prance 1991, 2001). At the present, ethnobotany becomes an interdisciplinary study that combines botany, linguistics, forestry, economics, conservation biology, pharmacology and so forth (Hamilton et al. 2003).

As previously mentioned, the study of medicinal plants is one of the more popular faces of ethnobotany. Before the development of modern allopathy, medicinal plants were essential to the mankind. However, for more than half of the world's population, they continue to serve as the primary source of medicine for health problems, which is especially true for people in developing countries (WHO 2002). Moreover, many of the modern allopathic drugs were developed out of traditional medicinal plants (Fabricant and Farnsworth
2001; Tu 2011) and the potential for a continuation of this is evident in the number of human cultures from around the world that boast considerable ethnomedicinal knowledge. It is estimated that there are around 50,000 species of plants in the world that have medicinal importance (Schippmann et al. 2002). However, only 28,187 of the world's medicinal plants have been recorded (Kew 2017). This number is merely a reflection of countries that have undertaken the study of ethnobotany in a serious capacity, with figures coming out of places like North America (Moerman 1996), Belize (Bourbonnas-Spear et al. 2005), Mexico (Leonti et al. 2003), the 'Cape' of South Africa, New Zealand, Nepal (SaslisLagoudakis et al. 2011), Southern African countries (Douwes et al. 2008), and Thailand (Phumthum et al. 2019). Nevertheless, many of these studies are still showing an incomplete numerical representation of medicinal species in their respective areas.

Even when the industrial revolution reached maximal influence in Thailand, the culture and lifestyle of the people safeguarded much of the traditional plant knowledge up until modern times. Some of this knowledge was empirically determined and routinely used by villagers (Phumthum and Balslev 2019) while other traditional medicines were developed via the influence of other nations, particularly from traditional Ayurvedic knowledge (Kurian 2012).

Thailand is a multiethnic country, with more than 70 languages and dialects spoken. The major number of these languages and dialects are spoken by ethnic minorities (Premsrirat 2004). These minority ethnic groups have incredible knowledge of medicinal plants as their livelihoods almost entirely depend on natural resources. In general, traditional knowledge in Thailand is transferred to the next generation orally, 
especially in the traditional knowledge systems of ethnic minorities: We seldom have written records of traditional knowledge, but among the selection that exist, most were written on Borassus leaf booklets (palm leaf rectangles: Ola) that are highly perishable. They generally succumb to destruction by moisture and termite feeding. Furthermore, all old records specified only local names, which is problematic because a singular local name can refer to multiple botanical entities, since medical nomenclature often ascribes names to species according to the therapeutic target rather than to the entity itself.

During the early 1900s, the pioneering Irish botanist and doctor, Arthur Francis George Kerr (1877-1942), developed an intense interest in the flora of Thailand. He navigated the country to collect plant specimens and record his insights. His botanical work has been described as comprehensive. Many succeeding botanists named new plant species in his honor, for example, Hoya kerrii Craib, Mussaenda kerrii Craib, Rafflesia kerrii Meijer and Quercus kerrii Craib. Fortunately, in some of Kerr's specimen descriptions, he also provided details of the uses by local people and also recorded a good chronological record of locations in his diary, which can now be found in the herbarium at the Royal Botanic Gardens, Kew in London. Due to his good note keeping, Kerr may be regarded as the first ethnobotanist of Thailand to give records of the uses of plants against their internationally known Latin binomial names. However, his works otherwise focused on pure botany, plant distributions, and plant identifications rather than ethnobotany.

After Kerr, the next to seriously study Thai ethnobotany was Edward Frederick Anderson (1932-2001) whose work first appeared in 1986, focusing on the tribal people in Chiang Rai Province (Anderson 1986a, b). His work constitutes the first appearance of the word 'ethnobotany' in the Thailand context, as it was written at the time in English. By consulting between Prof. Dr. Tem Smitinand, Dr. Weerachai Nanakorn, Dr. Dietrich Schmidt-Vogt, Dr. Ardith A. Eudey, and Dr. Hans T. Beck, in a national seminar regarding ethnobotany in 1991, the word 'ethnobotany' was translated into Thai as 'Preugsasartpuenbaan' and continues to be used today (Srithi 2012).

In 1991, Dr. Chusie Trisonthi proposed the first guidelines to kick-start the ethnobotanical discipline in Thailand. Under Dr. Trisonthi's guidance the 'Biodiversity and ethnobiology program' was established and promptly entered the curriculum at Chiang Mai University (Srithi 2012). Then in 1993 another book by Anderson was published on Thai ethnobotany entitled 'Plants and people of the Golden Triangle,' which describes the economic relationship between tribal people near the Golden Triangle in Thailand (Anderson 1993).

During the 1990s the rate of successfully completed ethnobotanical studies appearing in published literature starting gaining momentum and the geographical coverage started to expand across northern Thailand. Specifically, in the context of medicinal plant species, many use reports were included as part of broader ethnobotanical studies. Studies that focused solely on medicinal plants then started to come out of the work of Dr. Wongsatit Chuakul, affiliated with Mahidol University of central Thailand. Dr. Chuakul's team focused specifically on medicinal plants and this information was garnished from across several regions of Thailand, again expanding the reach of ethnobotanical field work.

In the last 10 years the momentum of ethnobotanical studies being published out 
of Thailand has increased considerably, bringing the country to the exalted level of international recognition for ethnobotanical field work. Today hundreds of villages have been visited; however, with approximately three decades of ethnomedicinal study, it is now necessary to summarize the breadth and coverage of this work to ensure that future work does not become repetitious or superfluous.

Therefore, this study aims to provide up to date information on the total number of ethnomedicinal studies based in Thailand since 1990, and to provide enough detail to guide decision making in the design and planning of future field work. Specifically, the objective is to answer the following questions: 1) How many ethnomedicinal studies have been completed in Thailand? 2) In which areas were those studies conducted? 3) How many ethnic groups were interviewed? 4) How many villages in those ethnic groups were studied? 5) Which areas or ethnic groups need to be focused on in future studies?

\section{MATERIAL AND METHODS}

Ethnomedicinal study reports related to medicinal plants in Thailand were garnished from online databases - Scopus, Google Scholar, and PubMed. Keywords related to 'medicinal plants,' 'ethnobotany,' and 'traditional medicine' were entered for searching reports. The other sources of data were university libraries and publications listed on the website of the Thai Library Integrated System (www.tdc.thailis.or.th). The site provides the biggest list of student theses, journal articles, and scientific reports from researchers working in all higher educational institutes in Thailand. This study ranked the importance of reports from high to low as student theses scientific reports, books, and journal articles, respectively. Therefore, the reports in the lower ranks that were published by the same author and focused on the same village were excluded. Institutional names were specified from students' supervisor institutions, the corresponding authors of journal articles, and the project manager who wrote scientific reports.

Although medicinal plants of Thailand appear in records dating as far back as the colonial period, in the current study the publication period of the reports was limited to the last 30-years, from 1990-2019. The reason is because the plant names in the reports must include scientific (Latin, binomial) names, and in 1991, ethnobotany was introduced to the Thai educational system and the use of Latin binomial names became mandatory. Thus, this study collected only reports that followed the currently accepted ethnobotanical methods for collecting data (Cotton 1996).

This study focused on the details of areas covered by previous studies (Supplementary Materials). First of all, village locations from the reports were extracted from the original reports. Village coordinates from the original reports were also used. In the case that village coordinates were lacking from original reports, village or sub-district coordinates were specified using the Google Earth application. Ethnic group names used in this study were the same names as specified in the original reports. In the case that the original reports did not provide ethnic names, this study included those people as a 'Thai ethnic group,' which connotes rural Thai people. Regions of studied villages were classified into seven regions according to the Thai floristic regions proposed by Tem Smitinand (Pooma and Suddee 2014). 


\section{RESULTS}

The current study counted 146 reports focused on ethnomedicinal studies in Thailand. The relative proportion of $y$ information sources is depicted in, which conveys that about half of all reports are student theses (75 theses). The next largest source of information came from journal articles, accounting for forty-six of the total reports. Sixteen percent were scientific reports, and a single book was also found.

As previously mentioned, the studies were published during 1990 to 2019. In the first decade (the 1990s), the total number of reports was only 17 . After that, the numbers increased continuously by 53 and 76 reports in the 2000s and 2010s respectively. However, the numbers of reports in the fiveyear intervals conveys the exponentiality of new report numbers. The first five-year period recorded the lowest number of reports (5 reports). Then, the numbers of studies increased by a further 12 during 1995-1999. In the following two five-year intervals (2000-2004 and 2005-2009), Thai ethnobotanical literature increased a further 25 and 28 respectively. The highest number of studied reports was recorded from 2010 to 2014 as 45 reports. But in the last five years the numbers have seen a slight recession, to 31 (Figure 1).

The affiliates of these above-mentioned studies were from 32 different universities and organizations. The highest number of studies were reported by Chiang Mai University (42 reports), followed by Kasetsart University with 22 reports. Prince of Songkla University and Mahidol University demonstrated numbers lower than 20, and Mahasarakham University reported only eight. Some universities, namely Naresuan Universiy, Burabha University, Mae Fah Luang University, Roi-Et Rajabhat University, and Suranaree University of Technology presented less than five. The other universities - Maejo University, Rajabhat universities, Rajamangala Universities, Thammasat University and Ubon Ratchathani University had only one or two reports (Figure 2a).

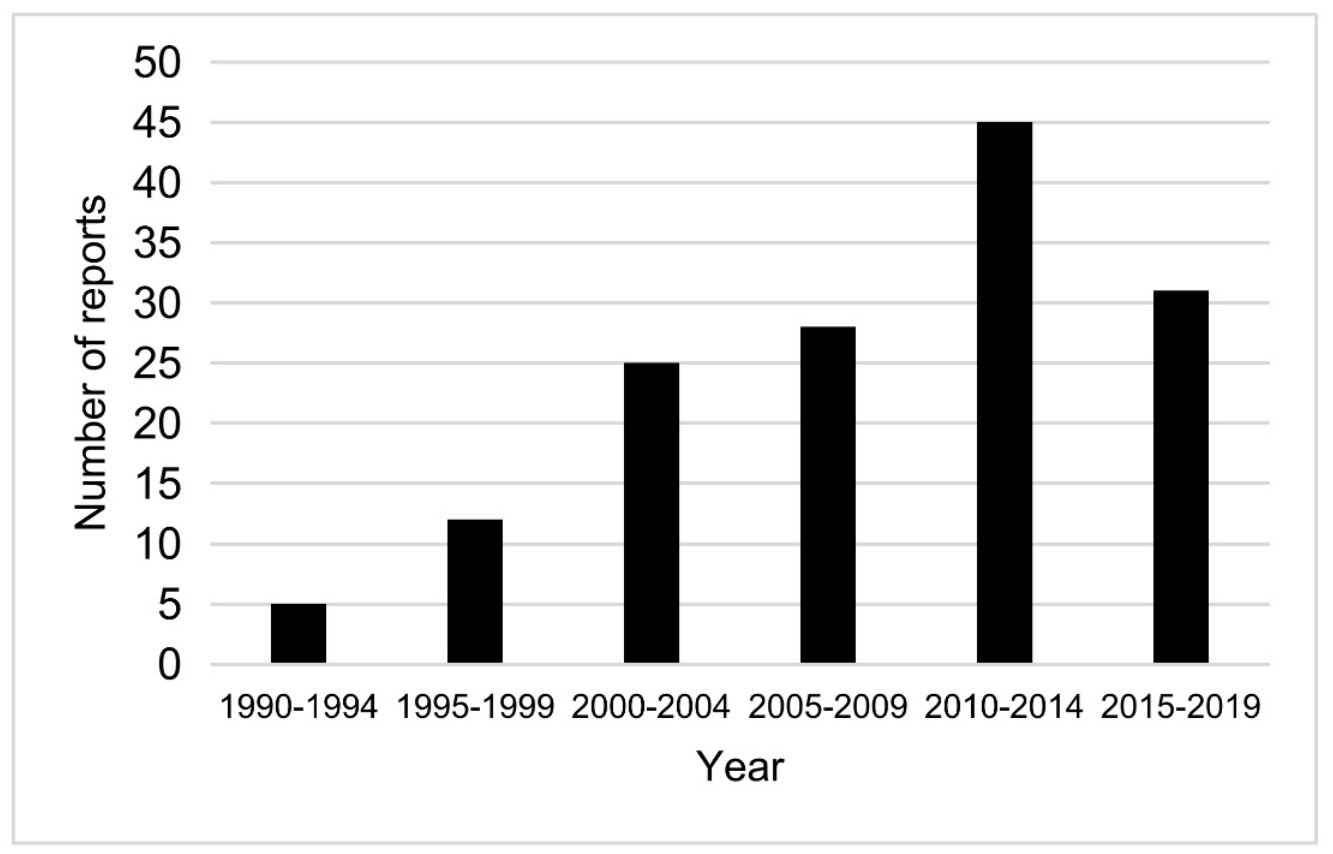

Figure 1. Numbers of ethnomedicinal study reports, which were conducted in Thailand, published in each five-year interval from 1990 to 2019. 

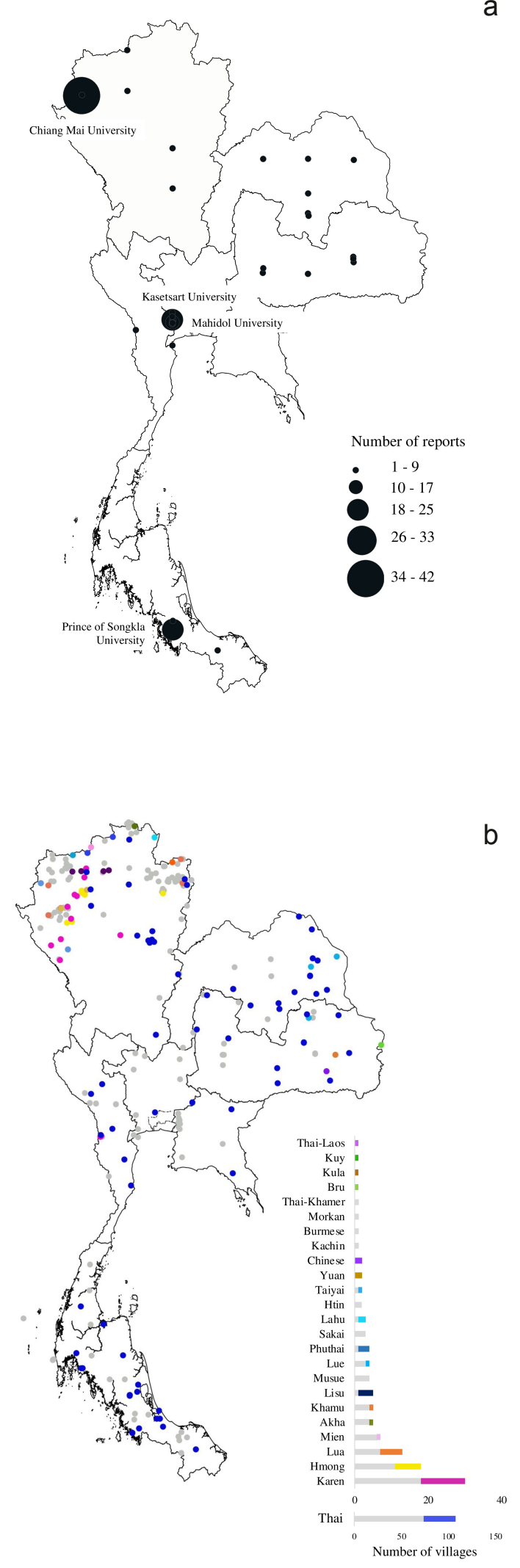

a

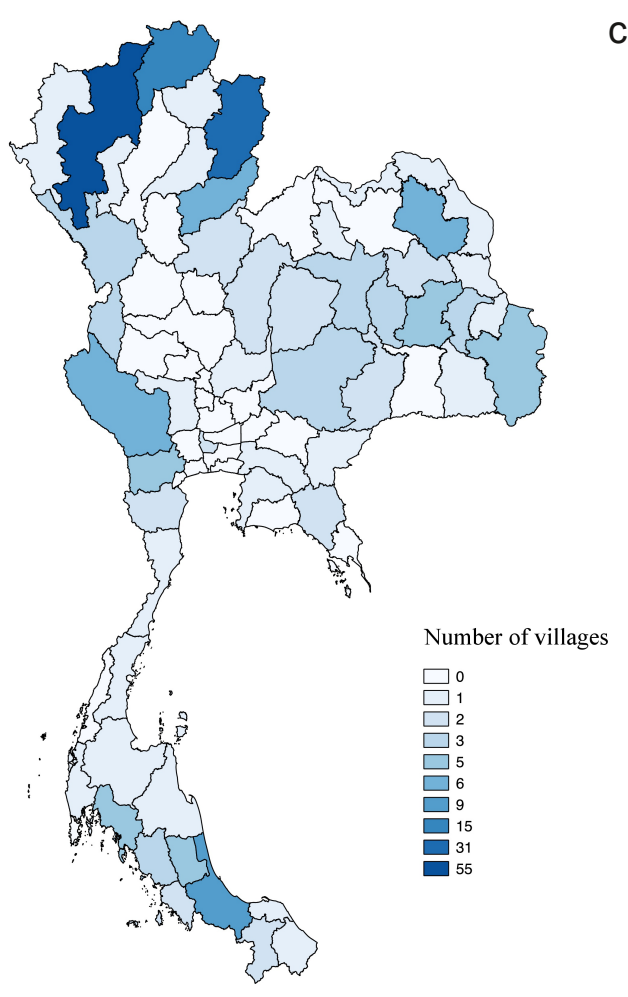

Figure 2. Locations of a) institutions that reported ethnomedicinal studies, b) studied villages reported ethnomedicinal information grey dots represent locations have been reported in Phumthum et al. (2018) and Phumthum and Balslev (2019), and other dot colors represent the new studied location that were not included in the studies which each color represent each ethnic group, and c) provinces show number of studied villages.

Out of these 146 reports, ethnomedicinal data was derived from 223 villages - 121 villages were summarized by Phumthum et al. (2018) and Phumthum and Balslev (2019); the others were mined from the literature. The villages covered in the studies are spread across all of the seven floristic regions in Thailand, covering 52 provinces (Figure 2b). The number of villages represented in ethnobotanical field work are shown for each province in Table 1. 
Table 1. Numbers of villages represented for each province by ethnomedicinal studies and field work. Province and No., which means number of villages.

\begin{tabular}{|c|c|c|c|c|c|c|c|}
\hline Province & No. & Province & No. & Province & No. & Village & No. \\
\hline Chiang Mai & 54 & Khon Kaen & 3 & Phitsanulok & 2 & Nakhon Phanom & 1 \\
\hline Nan Province & 33 & $\begin{array}{l}\text { Nakhon } \\
\text { Ratchasima }\end{array}$ & 3 & Satun & 2 & Nakhon Si Thammarat & 1 \\
\hline Chiang Rai & 15 & Sri Sa Ket & 3 & Yala & 2 & Nong Bua Lam Phu & 1 \\
\hline Songkhla & 9 & Tak & 3 & Amnat Charoen & 1 & Nong Kai & 1 \\
\hline Kanchanburi & 9 & Trang & 3 & Bung Kan & 1 & Pattani & 1 \\
\hline Sakon Nakhon & 9 & Yasothorn & 3 & Chachoengsao & 1 & Phangnga & 1 \\
\hline Uttaradit & 6 & Buri Ram & 2 & Chonburi & 1 & Phayao & 1 \\
\hline Krabi & 5 & Chaiyaphum & 2 & Chumphon & 1 & Phrae & 1 \\
\hline Phuttalung & 5 & Chantaburi & 2 & Lamphun & 1 & Prachuab Kiri Khan & 1 \\
\hline Ratchaburi & 5 & Mahasarakham & 2 & Lopburi & 1 & Si Sa Ket & 1 \\
\hline Ubon Ratchathani & 5 & Nontaburi & 2 & Mae Hong Son & 1 & Sra Kaew & 1 \\
\hline Roi Et & 4 & Phetchabun & 2 & Maha Sarakham & 1 & Suphanburi & 1 \\
\hline Kalasin & 3 & Phtchaburi & 2 & Mukdahan & 1 & Surat Thani & 1 \\
\hline
\end{tabular}

This information is also conveyed as a heat map against the geography of Thailand in Figure 2c, which clearly depicts a prevalence of field work in northern provinces. Northern Thailand had 117 villages visited for field work. The next highest concentration of ethnobotanical interviews was in the Peninsula (Southern Thailand), where 35 villages were visited. Then, 27 villages were the subject of studies in the Eastern region. In the northeastern region, interviews were conducted at 20 villages while 13 villages were visited in the southeastern provinces. Central and southeastern regions together had 11 studied villages in total (Figure $2 b$ and $2 c$ ).

Out of all of the field work that went into these studies precisely 25 ethnic groups were represented, which includes that rural Thai people, who made up almost half of all studied villages (108 villages). Not including the Thai ethnic people, the Karen was the most interviewed ethnic group, who were the subject of interviews spanning across 30 villages. Hmong and Lua had 18 and 13 studied villages, respectively. Seven studied villages were classified as Mien ethnic group. Each of Akha, Khamu, and Lisu had five studied villages. Twelve studied villages were from Lue, Musue, and Phuthai, equally. The other 14 ethnic groups provided 22 studied villages (Figures $2 \mathrm{~b}$ and $2 \mathrm{c}$ ).

\section{DISCUSSION}

From the time when ethnobotany had become a recognized academic discipline in Thailand until now, researchers from several of the country's highest educational institutions have continuously participated in the recording of traditional knowledge (Albuquerque et al. 2013). As can be seen in Figures 2a-c, the 146 ethnobotanical reports provide records of plant-use from all regions in Thailand. This figure overshadows the number of 66 out of all of the other 11 Southeast Asian countries, as of 2015 (Hidayati et al. 2015). This figure for all other Southeast Asian countries is less than half of that demonstrated by Thailand alone.

The current study conveys that 223 villages have been the subject of formal 
ethnobotanical studies during the last 30 years, divided into 25 ethnic groups. Surprisingly, this number was much higher than the numbers depicted in the previous study which reported only 121 studied villages from 19 ethnic groups (Phumthum et al. 2018). Among these ethnic groups in Thailand, the Thai ethnic group accounts for $91 \%$ of all representative populations. Therefore, it was no surprise that rural Thai people are the most represented group out of the studied villages (Figure 2b).

Thailand has 77 provinces, but the villages that have become the subject of ethnobotanical studies represent ethnobotanical uses of rural Thai people only 38 of those provinces, which is just under half (Figure $2 b$ and $2 c$ ). Apart from rural Thai people, around 6.1 million people classified into 56 ethnic groups. These people are divided into four major groups based on their settlement locations, which are highlands (hill-tribes) (13 groups), lowlands (38 groups), beaches (3 groups), and forests (2 groups) (SDHS 2014).

The Karen people are the second-most studied ethnic group. This might be because they have the biggest population among the hill-tribes (SDHS 2014). Moreover, Karen people are based in northern and western Thailand, which is the region that was most extensively explored by ethnobotanists in Chiang Mai University, led by Dr. Chusie Trisonthi, an avid ethnobotanist. This phenomenon relates to the result of the study in Latin America that the number of trained researchers reflects the number of scientific publications (Albuquerque et al. 2013). The abject attention of such a serious ethnobotanical team is evidently another reason why there are more studies on Karen villages than the other ethnic groups. This latter reason may also explain the extensive coverage of Hmong and Mien ethnic groups, which are also well-known ethnic groups in northern Thailand. However, these intensively recorded ethnic groups are a very tiny number compared to the other 70 ethnic groups livings in Thailand. Figure $2 \mathrm{~b}$ demonstrates that although there are a huge number of studied ethnic groups, the majority of them are only represented by a few of their villages. Not only does this alone hint that there is more to be discovered, by more comprehensively interviewing village herbalists in other villages of the previously investigated ethnic groups, but there are 45 other ethnic groups that have not been the subject of ethnobotanical study.

This current study demonstrates that researchers from many universities and research institutes across the country are interested in the subject area. With such a worthy collection of studies published in the literature or preserved in libraries, it is clear that Thailand has more than enough qualified ethnobotanists to take the discipline further. However, the vast majority of published and bound studies are restricted to a mere few universities (Figure 2a).

Although ethnobotanical studies in Thailand have been conducted on a grander scale compared to other Southeast Asian countries, the dramatic incremental increase of such studies since the 1990s is paralleled on a smaller scale in those other countries, especially South American countries (Albuquerque et al. 2013; Cámara-Leret et al. 2014). The general trend of Southeastern Asian countries as a whole is depicted by Hidayati et al. (2015) with figures taken from the years 1960 to 2014 . It is implicit that the same trend of growing participation in ethnobotanical studies can be seen more concertedly across this part of the world, particularly in the periods of 2005-2009 and 2010-2014 (Albuquerque et al. 2013; Guerrero-Gatica et al. 2020; Hidayati et al. 
2015). However, Figure 1 depicts a dip in the number of reports in Thailand to 31 in the most recent five years, and this is a trend that may be occurring in surrounding countries. In this case, it is necessary that researchers and the Thai government, including other organizations, show support for the continuation of research into ethnomedicine.

Ethnobotany became well-known in 1895 due to the successes and publication of Harshberger's work in North America (Harshberger 1896). It was gradually accepted as an academic discipline during the 1900s and then enjoyed widespread participation in other parts of the world. During the course of more than a century, the discipline has graduated through a number of evolutionary phases to become what it is today. That period can be subdivided into five phases, wherein phase I can be described as a time of documentation of useful plants and animals (1895-1950), and phase II: a time of cognitive ethnobiology (1950s - 1970s). In keeping with the global paradigm of environmental sensitivity, phase III is when ethnobiology became integrated with the ethnoecological concept (1970s - 1980s). Phase IV set the precedent for the current model, where the development of collaborative research (1990s), brought about phase $\mathrm{V}$, a truly interdisciplinary research discipline (Clément 1998; Hunn 2007; Wyndham et al. 2011).

It is of interest to note that during the past 30 years of ethnobotanical research in Thailand, the discipline has passed through all of the above-mentioned phases. For example, most of the studies during the first two decades put emphasis on pure documentation, while many reports published in the last decade have branched out to embrace the applied ethnomedicinal paradigm that integrates many related fields
(Junsongduang et al. 2014; Panyadee et al. 2018; Phumthum and Balslev 2019; Phumthum et al. 2019; Tangjitman et al. 2015). However, such studies that convey this interdisciplinary scope are but only a few. This phase is crucial in the ethnobotanical study because collaborations among scientists, especially from different nationalities, imply the scientific maturity of the discipline (Campos et al. 2016). Hence, they may be considered as the foundation of the latter phases.

Moreover, even with the great progress that has been made, the data does not cover all 77 provinces of the country. Also, the number of studied villages is very tiny compared to over 70,000 villages in Thailand. Furthermore, the number of ethnic groups that have participated in studies is only a representative of a third of the total number in the country. It is alarming that such work has not been elevated to a national priority, since many of the ethnic group's languages are estimated to be on the verge of extinction (Currie and Mace, 2012).

Out of the groups that have been studied intensively, i.e., Karen, Hmong, Mien, there is still so much work left to do. Field work in more villages of the same ethnic groups are predicted to continue to yield new and interesting discoveries, because the villages previously broached are still geographically isolated from other language regions. It has already been demonstrated that ethnomedicinal knowledge of each village in the same ethnic group is unique (Phumthum and Balslev 2019). A meta-analysis in 2018 revealed the vast number of ethnomedicinal plants in Thailand that were discovered from field work in just 121 villages ( $22 \%$ of all Thai plants). Nevertheless, that number fell well below the total number of medicinal plant species in Thailand (Phumthum et al. 
2018). Documentation of ethnomedicinal knowledge (phase I) in Thailand is needed not only for completing the overall Thai ethnomedicinal flora but also to compete against the destructive force of traditional knowledge erosion, which is of global concern (Srithi et al. 2009; Voeks and Leony, 2004).

\section{CONCLUSIONS}

During the last 30 years a sum total of 146 ethnomedicinal reports were published. Moreover, the number of publications on a per year basis was on average increasing until recently. Most publications were in the form of students' theses and journal articles. Those reports were published by researchers from many universities and research institutes in Thailand, especially, Chiang Mai University, Kasetsart University, Prince of Songkla University, and Mahidol University. Over 200 villages were studied, from 25 ethnic groups in Thailand. However, this study found that although the studied villages are widely distributed across Thailand and cover a lot of studied ethnic groups, more ethnomedicinal studies need to be conducted to more wholly collect and preserve the ethnomedicinal knowledge.

\section{ACKNOWLEDGEMENTS}

I am thankful to Dr. Nicholas J. Sadgrove from the Royal Botanic Gardens, Kew, for helping in English proofreading this manuscript. This research project was supported by Mahidol University.

\section{CONFLICTS OF INTEREST}

The author has no conflicts of interest to declare.

\section{REFERENCES}

Albuquerque UP, Silva JS, Campos JLA, Sousa RS, Silva TC, Alves RRN (2013) The current status of ethnobiological research in Latin America: gaps and perspectives. Journal of Ethnobiology and Ethnomedicine 9(72).

Anderson EF (1986a). Ethnobotany of hill tribes of northern Thailand. I. Medicinal plants of Akha. Economic Botany 40:38-53

Anderson EF (1986b). Ethnobotany of hill tribes of Northern Thailand. II. Lahu medicinal plants. Economic Botany 40:442-450.

Anderson EF (1993). Plants and people of the Golden Triangle. Ethnobotany of the hill tribes of northern Thailand. Dioscorides Press, Portland.

Bourbonnas-Spear N, Awad R, Maquin P, Cal V, Vindas, PS, Poveda L, Arnason JT (2005) Plant use by the q'eqchi' maya of belize in ethnopsychiatry and neurological pathology. Economic Botany 59(4): 326-336.

Campos JLA, Sobral A, Silva JS, Araújo TAS, Ferreira-Júnior WS, Santoro FR, dos Santos GC, Albuquerque UP (2016) Insularity and citation behavior of scientific articles in young fields: the case of ethnobiology. Scientometrics 109, 1037-1055

Cámara-Leret R, Paniagua-Zambrana N, Balslev H, Macía MJ (2014) Ethnobotanical knowledge is vastly under-documented in northwestern South America. PloS one 9

Clément D (1998) The historical foundations of ethnobiology (1860-1899). Journal of Ethnobiology 18(2): 161-187.

Cotton CM (1996) Ethnobotany Principles and Applications. John Wiley \& Sons, Ontario.

Currie TE, Mace R (2012) The evolution of ethnolinguistic diversity. Advances in Complex Systems 15(01n02): 1150006.

Douwes E, Crouch NR, Edwards TJ, Mulholland DA (2008) Regression analyses of southern African ethnomedicinal plants: informing the targeted selection of bioprospecting and pharmacological screening subjects. Journal of Ethnopharmacology 119(3): 356-364.

Fabricant DS, Farnsworth NR (2001). The value of plants used in traditional medicine for drug discovery. Environmental Health Perspectives 109(Suppl 1): 69-75. 
Guerrero-Gatica M, Mujica MI, Barceló M, VioGaray MF, Gelcich S, Armesto JJ. (2020) Traditional and Local Knowledge in Chile: Review of Experiences and Insights for Management and Sustainability. Sustainability. 12(5):1767.

Hamilton A, Shengji P, Kessy J, Khan AA, LagosWitte S, Shinwari ZK (2003) The purposes and teaching of applied ethnobotany. United Nations Educational, Scientific and Cultural Organization (UNESCO).

Harshberger JW (1896) The purposes of ethnobotany. Botanical gazette 21(3): 146-154.

Hidayati S, Franco FM, Bussman RW (2015) Ready for phase 5 - current state of ethnobiolgoy in Southeast Asia. Journal of Ethnobiology and Ethnomedicine 11: 17.

Hunn E (2007) Ethnobiology in four phases. Journal of Ethnobiology 27(1): 1-10

Junsongduang $A$, Balslev $H$, Inta A, Jampeetong A, Wangpakapattanawong $P$ (2014) Karen and Lawa medicinal plant use: Uniformity or ethnic divergence? Journal of Ethnopharmacology 151(1): 517-527.

Kew (2017) State of the World's Plants 2017. Royal Botanic Gardens Kew, London. https:// stateoftheworldsplants.com. (Accessed 14-07 2017).

Kurian JC (2012) Ethno-medicinal Plants of India, Thailand and Vietnam. Journal of Biodiversity 3(1): 61-75.

Leonti M, Fernando RR, Sticher O, Heinrich M (2003) Medicinal Flora of the Popoluca, Mexico: A botanical systematical perspective. Economic Botany 57(2): 218-230.

Moerman DE (1996) An analysis of the food plants and drug plants of native North America. Journal of Ethnopharmacology 52(1): 1-22.

Panyadee $\mathrm{P}$, Balslev $\mathrm{H}$, Wangpakapattanawong P, Inta A, (2018) Karen Homegardens: Characteristics, Functions, and Species Diversity. Economic Botany 72(1): 1-19.

Phumthum M, Balslev $\mathrm{H}$ (2019) Use of Medicinal Plants Among Thai Ethnic Groups: A Comparison. Economic Botany 73(1): 64-75.

Phumthum M, Balslev H, Barfod AS (2019) Important Medicinal Plant Families in Thailand. Frontiers in Pharmacology 10(1125).
Phumthum $M$, Srithi $K$, Inta $A$, Junsongduang $A$, Tangjitman K, Pongamornkul W, Trisonthi C, Balslev H (2018) Ethnomedicinal plant diversity in Thailand. Journal of Ethnopharmacology 214: 90-98.

Pooma R, Suddee S (2014) Tem Smitinand's Thai Plant Names, revised. The Office of the Forest Herbarium, Department of National Parks, Wildlife and Plant Conservation, Bangkok.

Prance GT (1991) What is ethnobotany today? Journal of Ethnopharmacology 32(1): 209-216.

Prance GT (2001) Richard Evans Schultes (12 January 1915-10 April 2001): A tribute. Economic Botany 55(3): 347.

Premsrirat S (2004) Ethnolinguistic maps of Thailand. Ministry of Culture and Mahidol University, Bangkok.

Saslis-Lagoudakis $\mathrm{CH}$, Williamson EM, Savolainen V, Hawkins JA (2011) Cross-cultural comparison of three medicinal floras and implications for bioprospecting strategies. Journal of Ethnopharmacology 135(2): 476-487.

Schippmann U, Leaman DJ, Cunningham A (2002) Impact of cultivation and gathering of medicinal plants on biodiversity: global trends and issues. Biodiversity and the ecosystem approach in agriculture, forestry and fisheries.

SDHS (2014) Master plan: Development of ethnic groups in Thailand (2015-2018). Ministry of Social Development and Human Security, Bangkok.

Srithi K (2012) Comparative ethnobotany in Nan Province, Thailand. Chiang Mai University, Chiang Mai.

Srithi K, Balslev H, Wangpakapattanawong P, Srisanga P, Trisonthi C (2009) Medicinal plant knowledge and its erosion among the Mien (Yao) in northern Thailand. Journal of Ethnopharmacology 123(2): 335-342.

Tangjitman K, Trisonthi C, Wongsawad C, Jitaree S, Svenning J-C (2015) Potential impact of climatic change on medicinal plants used in the Karen women's health care in northern Thailand. Songklanakarin Journal of Science and Technology 37(3): 369-379.

Touwaide A, Pollio A, Aliotta G, Piomelli D, De Santo NG (1997) Medicinal Plants for the Treatment of Urogenital Tract Pathologies According to Dioscorides 'De Materia Medica'. American Journal of Nephrology 17(34): 241-247. 
Tu Y (2011) The discovery of artemisinin (qinghaosu) and gifts from Chinese medicine. Nature Medicine 17: 1217.

Voeks RA, Leony A (2004) Forgetting the forest: Assessing medicinal plant erosion in Eastern Brazil. Economic Botany 58(1): S294S306.
WHO (2002) WHO traditional medicine strategy 2002-2005. World Health Organization, Geneva.

Wyndham FS, Lepofsky D, Tiffany S (2011) Taking stock in ethnobiology: Where do we come from? What are we? Where are we going? Journal of Ethnobiology 31(1): 110-127, 118.
Received: 23 April 2020

Accepted: 20 May 2020

Published: 22 May 2020 